\title{
Effects of changes in seagrass shoot density and leaf height on abundances and distribution patterns of juveniles of three gobiid fishes in a Zostera marina bed
}

\author{
Masahiro Horinouchi*, Mitsuhiko Sano \\ Department of Global Agricultural Sciences, Graduate School of Agricultural and Life Sciences, \\ University of Tokyo, Yayoi, Bunkyo-ku, Tokyo 113-8657, Japan
}

\begin{abstract}
The effects of changes in the structural complexity of a seagrass Zostera marina habitat on the densities of juveniles of 3 gobiid fishes, Pterogobius zonoleucus, Chaenogobius heptacanthus and Chasmichthys gulosus, were investigated by field experimentation at Moroiso and Aburatsubo Bays, Miura Peninsula, Japan. Following seagrass manipulation, involving reduction of leaf heights and shoot densities as well as complete removal of seagrass, juvenile densities of all 3 gobiids were found to be higher in those quadrats with sparser or shorter seagrass, the abundance in the seagrass-cleared quadrat always being greater than that in the control. In the quadrat with the lowest shoot density, juveniles resided among the shoots, and were evenly distributed over a horizontal plane. In the quadrat with the shortest seagrass, juveniles appeared above the canopy, and were positioned as in the seagrass-cleared quadrat, i.e. near the surrounding walls of untreated seagrass. By contrast, in the experimental patches lacking surrounding walls of unmanipulated seagrass, no juveniles appeared. The results indicated that water column-distributed juveniles of the 3 gobiid species prefer sparser seagrass and open areas close to the wall of untreated seagrass.
\end{abstract}

KEY WORDS: Habitat complexity Seagrass bed · Gobiid juveniles

\section{INTRODUCTION}

Seagrass beds support large numbers of fish species and individuals, and provide nursery habitats for juveniles of many species, as compared to adjacent unvegetated areas which have different fish assemblages, usually characterized by fewer species and fewer individuals (e.g. Kikuchi 1974, Adams 1976, Weinstein \& Heck 1979, Beckley 1983, Pollard 1984, Bell \& Pollard 1989, Sogard 1992, Connoly 1994a, Edgar \& Shaw 1995). In many studies, greater fish abundances in denser seagrass has been documented (e.g. Adams 1976, Orth \& Heck 1980, Leber 1985, Bell \& Westoby $1986 \mathrm{a}, \mathrm{b}, \mathrm{c}$, Worthington et al. 1992); habitat complexity,

·E-mail: adiver@hongo.ecc.u-tokyo.ac.jp structured by seagrass, is considered one of the major factors responsible for such differences in habitat use. Greater habitat complexity provides shelter from predation, increased microhabitat availability and more diverse and abundant prey, thereby strongly influencing mortality and growth rates of individual fish (Crowder \& Cooper 1982, Gilinsky 1984, Diehl 1993, Diehl \& Eklöv 1995) and, ultimately, population size.

Direct examination of the effects of structural complexity within seagrass beds on fish diversity and abundance is most easily made by manipulation of the natural seagrass. To date, several field experiments in natural seagrass beds have been conducted and have provided in different explanations for the different responses of fishes to altered structural complexity. After manipulating seagrass densities along with predator exclusion cages, Bell \& Westoby (1986c) 
found greater numbers of small fish in denser seagrass, regardless of predator absence, due to fish preference for a more complex habitat. Connoly (1994b) showed, on the other hand, that removal of the seagrass canopy had no affect on densities of non-pelagic small fishes. Similarly, Horinouchi et al. (1999) found that alterations in seagrass shoot density and leaf height had no affect on small benthic goby density.

The gobiid fishes Pterogobius zonoleucus, Chaenogobius heptacanthus and Chasmichthys gulosus are common species widely distributed along the Japanese coast. The former 2 species occupy the water column throughout their lives, whereas the latter occupies the water column early in life, but later becomes benthic (Akihito 1988). Whereas P. zonoleucus commonly utilizes Zostera beds as one of its habitats throughout its life, the other 2 species reside in Zostera beds only during their juvenile phase and seldom appear in these beds thereafter. At the present study sites during May and June, many juveniles of the 3 gobies occur in the water column, often forming mixed groups of 2 or 3 species. These juveniles are planktivorous, with translucent bodies up to about $30 \mathrm{~mm}$ in total length. After June, most of these fishes leave the Zostera habitats.

In the present study, we tested the predictions of previous studies concerning patterns of variation in abundances of small fish in relation to habitat complexity. Specifically, the purpose of the present study was to determine the effects of alterations in structural complexity (shoot density and leaf height of seagrass) on abundances and distribution patterns of juveniles of the above 3 gobiid fishes in a naturally occurring Zostera bed.

\section{MATERIALS AND METHODS}

Study site. The study was carried out within the adjoining bays of Moroiso and Aburatsubo (35 $09^{\prime} \mathrm{N}$, $\left.139^{\circ} 37^{\prime} \mathrm{E}\right)$ on the southwestern side of Miura Peninsula, Kanagawa Prefecture, Japan, in May and June 1996 (Fig. 1). A monospecific Zostera marina bed (ca 2 ha) within Moroiso Bay and 5 isolated monospecific Z. marina patches (ca $30 \mathrm{~m}^{2}$ in minimum, $50 \mathrm{~m}^{2}$ in maximum and $35 \mathrm{~m}^{2}$ in median) within Aburatsubo Bay were chosen for the experiments.

Manipulation of habitat complexity. Eight $5 \mathrm{~m} \times 5 \mathrm{~m}$ quadrats, separated from each other by at least $5 \mathrm{~m}$, were established within $20 \mathrm{~m}$ of the inshore edge of the bed in Moroiso Bay at depths between 1.5 and $2.0 \mathrm{~m}$ at low tide. The experimental design involved 7 seagrass treatments, each restricted to a single quadrat: seagrass shoot densities were reduced to (1) one quarter, (2) one half and (3) three quarters of the density in the control quadrat; leaves were shortened to (4) one quarter, (5) one half and (6) three quarters of the leaf height

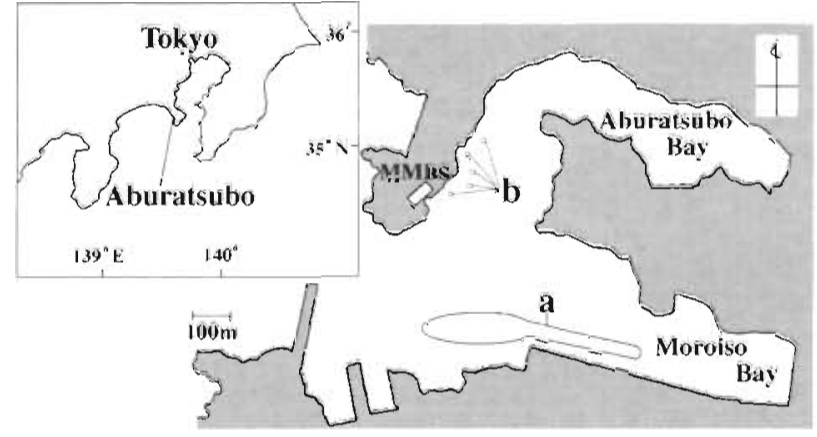

Fig. 1. Map of the study site. a: experimental Zostera marina bed $_{i}$ b: experimental $Z$. marina patches. MMBS: Misaki Marine Biological Station, University of Tokyo

in the control quadrat. In treatment (7) all of the seagrass in the quadrat was removed. The final quadrat (8) was established as the control.

In the leaf height-manipulations, distal ends of leaves were clipped with shears. In the seagrass shoot density or seagrass-cleared manipulations, entire shoots along with rhizomes were removed.

Leaf height was expressed as the mean length of 5 leaves chosen randomly within each quadrat. Five transects were laid in each quadrat using a scaled tape and ruler. All shoots within each transect were counted, shoot density being expressed as the mean number of shoots per $0.1 \mathrm{~m}^{2}(\mathrm{n}=5)$. Prior to seagrass manipulations, no differences in leaf height or shoot density were apparent among the quadrats (1-way ANOVA, $F_{7,32}=0.6, \mathrm{p}>0.7$ for leaf heights; $F_{7,32}=0.2$, $p>0.9$ for shoot densities). After seagrass manipulations, leaf heights and shoot densities were checked weekly and, where necessary, manipulated so as to maintain the initial condition of each treatment. Such manipulations were conducted very carefully in order not to disturb fishes.

Bordering the 3 leaf height-manipulated quadrats and the seagrass-cleared quadrat were walls of untreated leaves. To evaluate the effects of such walls, 5 isolated Zostera marina patches, separated from each other by at least $30 \mathrm{~m}$, were selected in Aburatsubo Bay at depths between 1.5 and $2.0 \mathrm{~m}$ at low tide. The same leaf height treatments as in the quadrats in Moroiso Bay, each restricted to a single patch, were conducted over the whole of each patch. The final patch was established as a control. Prior to seagrass manipulations in patches, no differences in leaf height or shoot density of seagrass were apparent among these patches and the Moroiso Bay control quadrat (1-way ANOVA, $F_{5,24}=0.3, p>0.9$ for leaf heights; $F_{5.24}=0.47, \mathrm{p}>0.7$ for shoot densities).

Visual estimate of fish density. In each experimental quadrat in the Zostera bed in Moroiso Bay, 25 blocks 
$1 \mathrm{~m}$ square were established using a scaled tape. Thirteen blocks, excluding the 4 corners of the quadrat, were selected systematically. Of the former, 8 blocks (hereafter termed marginal blocks) adjoined unmanipulated seagrass surrounding the quadrat, unlike the remaining 5 (hereafter termed central blocks). Using SCUBA, all juveniles of the 3 gobiid species within each block were counted and their positions relative to the seagrass recorded visually between 10:00 and 14:00 h on 8 May and on 12 and 26 June 1996. In the control quadrat, the mean seagrass density on 8 May and 12 and 26 June was $17.6( \pm 1.5 \mathrm{SD}), 13.8( \pm 2.2 \mathrm{SD})$ and $13.6( \pm 1.0 \mathrm{SD})$ shoots per $0.1 \mathrm{~m}^{2}(\mathrm{n}=5)$, respectively, and the mean leaf height $124( \pm 23.8 \mathrm{SD}) \mathrm{cm}$, $116( \pm 8.3 \mathrm{SD}) \mathrm{cm}$ and $114.4( \pm 10.4 \mathrm{SD}) \mathrm{cm}(\mathrm{n}=5)$, respectively. Juveniles often occurred in mixed-species groups. When a large number of individuals occurred in a group, their number was approximated by initially estimating the volume of water containing 10 individuals, and by then converting it into the estimated total volume of water containing the group. Surveys were made at least $4 \mathrm{~d}$ after any manipulations of seagrass. Within each of the 5 experimental patches in Aburatsubo Bay, 13 blocks $(1 \mathrm{~m} \times 1 \mathrm{~m}$ ) were established in the same way as those in Moroiso Bay. A visual survey was conducted on 28 June. Prior to seagrass manipulations, the fish densities were visually surveyed, revealing no differences in fish abundance among the quadrats (Kruskal-Wallis test, p > 0.8 for each fish species) and among the patches (Kruskal-Wallis test, $\mathrm{p}>0.8$ for each fish species).

Statistical analysis. Since fish were not observed in all quadrats, the assumption of homogeneity of variances for parametric analysis could not be met. Therefore, the non-parametric Kruskal-Wallis analysis was employed to test if juvenile dersities differed among the quadrats. If the difference in fish densities among the quadrats was significant $(p<0.05)$, the density was compared between all possible pairs of quadrats using the Tukey's $Q$-test. Statistical analyses of the juvenile responses to the alterations in structural complexity of the patches were not conducted because no fish occurred in the seagrass height-manipulated and seagrass-cleared patches (see 'Results').
To evaluate horizontal and vertical distribution patterns of juveniles within each quadrat, fish densities were compared between marginal and central blocks, and between the water column within the seagrass canopy and that from the canopy top to the surface, using the Mann-Whitney test. Tied-rank adjustments were conducted in these analyses.

\section{RESULTS}

\section{Juvenile abundance in the experimental quadrats}

A greater abundance of juveniles of the 3 gobies occurred in the quadrats with sparser or shorter seagrass, although such was not always statistically significant (Fig. 2). Examination of the 3 species pooled showed a significant effect of Zostera density on fish

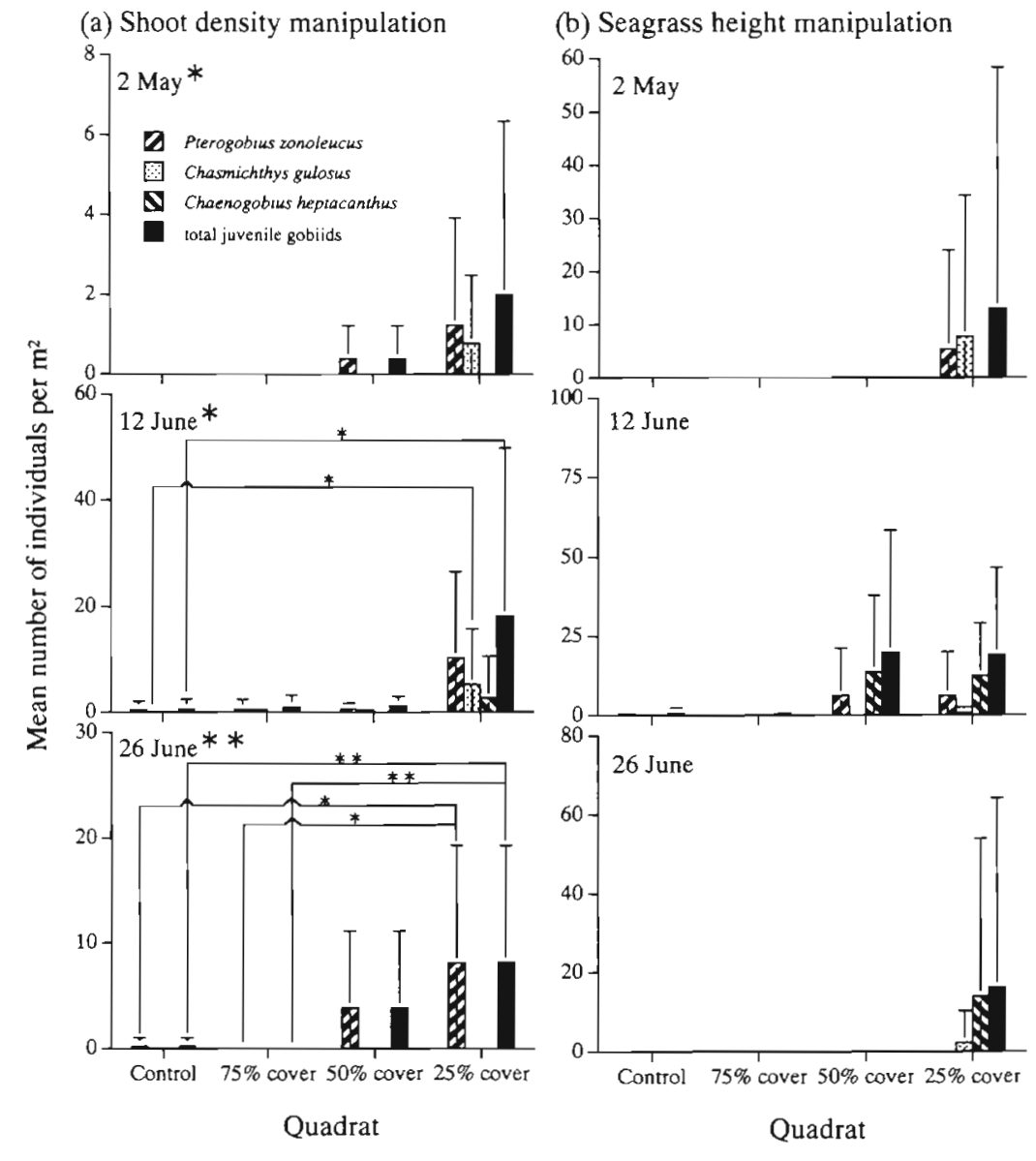

Fig. 2. Mean numbers of gobiid juveniles $\mathrm{m}^{-2}$ within quadrats manipulated for (a) seagrass shoot density and (b) seagrass height. Asterisked months indicate significant differences in juvenile densities of all gobiid species among quadrats (Kruskal-Wallis test). Asterisked horizontal bars indicate significant differences in juvenile densities between quadrats (Tukey's $Q$-test). ' $p<0.05$; $\cdots p<0.01$. Bars indicate standard deviation 
abundance (Kruskal-Wallis test, Fig. 2a). On 12 June, total gobiid density in the quadrat with one quarter control shoot density (25\% cover) was significantly higher than that in the control quadrat (Tukey's Q-test, Fig. 2a). On 26 June, total gobiid density in the quadrat with one quarter control shoot density was significantly higher than that in the control quadrat and that with 3 quarters control shoot density (75\% cover) (Tukey's Q-test, Fig. 2a). For individual species, increasing densities in quadrats with sparser seagrass were apparent, although significant only for Chasmichthys gulosus on 12 June and Pterogobius zonoleucus on 12 and 26 June (Kruskal-Wallis test, C. gulosus $\mathrm{p}<0.05$; P. zonoleucus, on 12 June, $\mathrm{p}<0.05$, and on 26 June, $\mathrm{p}<0.01$, respectively). The density of C. gulosus in the quadrat with one quarter control shoot density was significantly higher than that in the control quadrat (Tukey's $Q$-test, Fig. 2a). For P. zonoleucus on 12 June, increasing densities in quadrats with sparser seagrass were apparent, although the Tukey's Q-test did not detect the difference in fish density between any pair of quadrats. On 26 June, the density of $P$. zonoleucus in the quadrat with one quarter control shoot density was significantly higher than those in the control or 3 quarters control shoot density quadrats (Tukey's Q-test, Fig. 2a).

More juveniles of the 3 gobiids appeared in the quadrats with shorter seagrass, although the differences in pooled species densities among leaf height-manipulated quadrats were not statistically significant (KruskalWallis test, Fig. 2b). On 12 June, the difference in pooled species densities among leaf height-manipulated quadrats was marginally significant (Kruskal-Wallis test, $p=0.06$ ), although the Tukey's $Q$-test did not detect the difference in fish abundance between any pair of quadrats (Fig. 2b). For individual species, juvenile densities seemed to increase in the quadrats with shorter seagrass but were not statistically significant.

The pooled species abundance in the seagrasscleared quadrat $(0 \%$ cover) always appeared to be

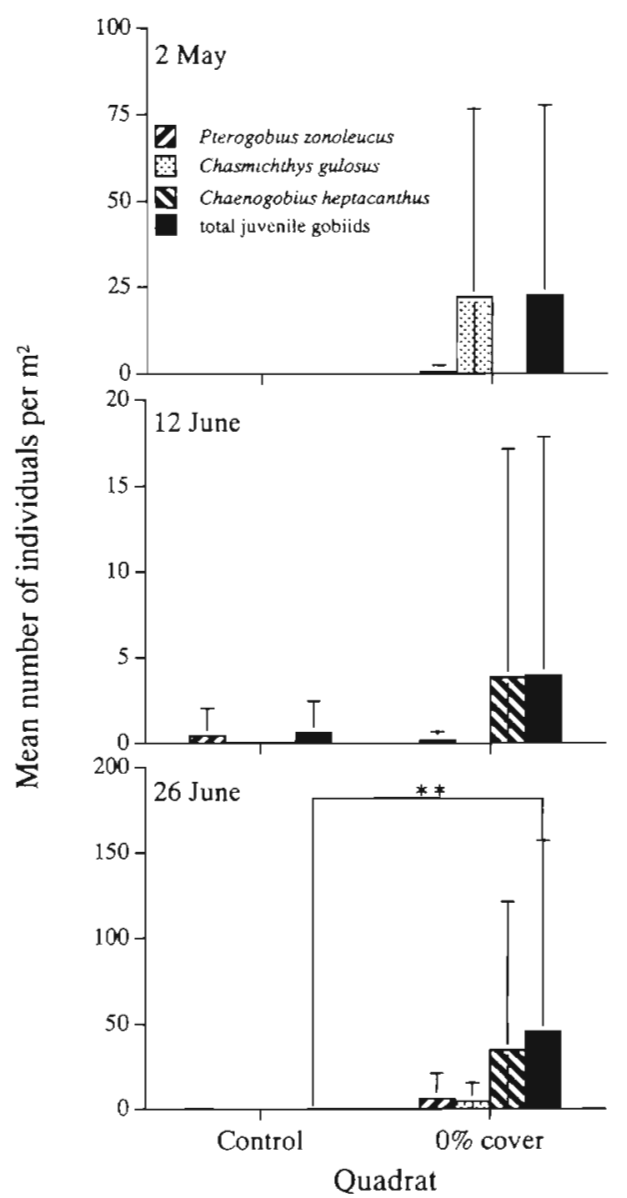

Fig. 3. Mean numbers of gobiid juveniles $\mathrm{m}^{-2}$ within seagrasscleared and control quadrats. Asterisked horizontal bar indicates significant difference in juvenile densities between quadrats (Mann-Whitney test). $\cdots p<0.01$. Bars indicate standard deviation

greater than that in the control quadrat, although the difference in density between these quadrats was statistically significant only on 26 June (Mann-Whitney test, $p<0.01$, Fig. 3). Densities of each species, how-

Table 1 Pterogobius zonoleucus, Chaenogobius heptacanthus and Chasmichthys gulosus. Frequency distribution of group size (number of individuals per group) in each experimental quadrat established in the Zostera marina bed at Moroiso Bay during the 3 d census

\begin{tabular}{|c|c|c|c|c|c|c|c|c|}
\hline \multirow{3}{*}{$\begin{array}{l}\text { No. of } \\
\text { individuals }\end{array}$} & \multirow{3}{*}{ Control } & \multicolumn{6}{|c|}{ Quadrats } & \multirow{3}{*}{ Seagrass-cleared } \\
\hline & & \multicolumn{3}{|c|}{ Shoot density manipulation } & \multicolumn{3}{|c|}{ Seagrass height manipulation } & \\
\hline & & $25 \%$ off & $50 \%$ off & $75 \%$ off & $25 \%$ off & $50 \%$ off & $75 \%$ off & \\
\hline Solitary & 5 & 1 & 6 & 8 & 1 & 2 & 2 & 1 \\
\hline $2-10$ & 1 & 4 & 7 & 5 & 1 & & & \\
\hline $11-20$ & & & 1 & 8 & & 1 & 1 & 2 \\
\hline $21-30$ & & & 1 & 2 & & 1 & 2 & \\
\hline $31-40$ & & & & 1 & & & & \\
\hline $41-50$ & & & & & & 2 & 1 & \\
\hline$>50$ & & & & 1 & & & 4 & 8 \\
\hline
\end{tabular}


ever, did not differ significantly between the 2 quadrats. The group size (i.e. the number of individuals per group) tended to increase in quadrats with sparser or shorter seagrass (Table 1). In untreated seagrass, juveniles often occurred individually or in small groups of no more than 10 members. In the quadrat with one quarter control density, groups of 11 to 20 juveniles occurred most often, compared with large groups of 50 or more in one quarter control leaf height and seagrass-cleared quadrats.

\section{Juvenile abundance in the experimental patches}

Several individuals of Pterogobius zonoleucus appeared in the control patch, but no fishes occurred in experimental patches manipulated for seagrass height or entirely cleared of seagrass (Fig, 4).

\section{Distributions of juveniles in the experimental quadrats}

Analysis of the distribution patterns of juveniles in the quadrats with one quarter control shoot density or leaf height, and in the seagrass-cleared quadrat, resulted in the following:

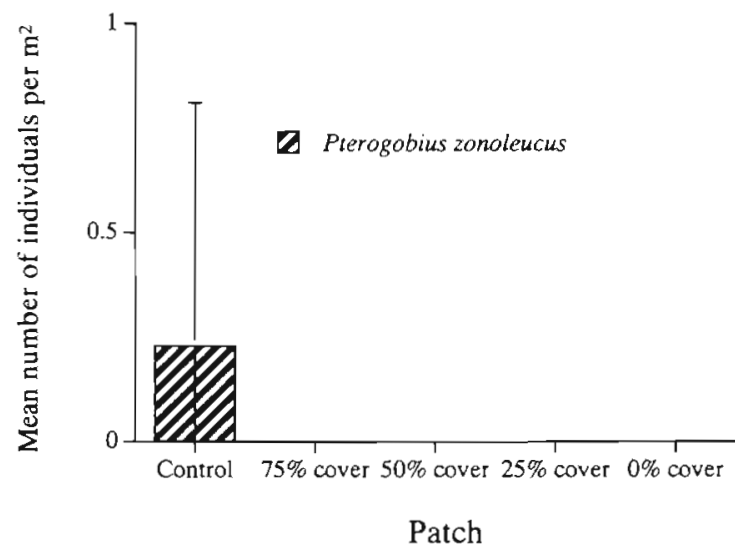

Fig. 4. Mean numbers of gobiid juveniles $\mathrm{m}^{-2}$ (Pterogobius zonoleucus only present) within patches manipulated for seagrass height. Bars indicate standard deviation

\section{Horizontal distribution}

In the quadrat with one quarter control shoot density, juvenile abundances of individual or pooled species did not differ between the marginal and central blocks (Mann-Whitney test, all $\mathrm{p}>0.05$ ) (Fig. 5a). In the quadrat with one quarter control leaf height, however, almost all of the juveniles occurred in the marginal

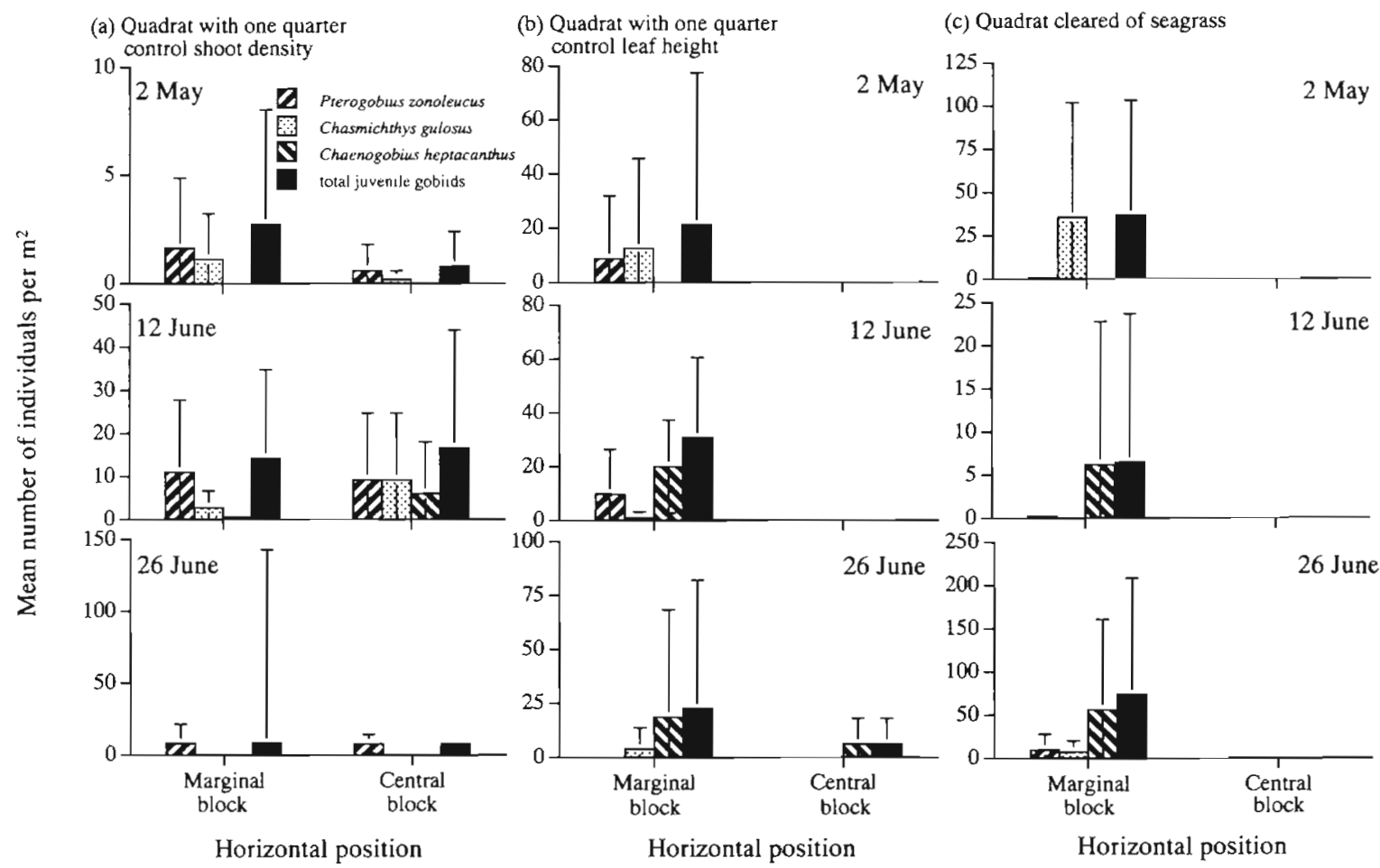

Fig. 5. Horizontal distribution of gobiid juveniles in quadrats with (a) one quarter control shoot density, (b) one quarter control leaf height and (c) the seagrass-cleared quadrat. Marginal and central blocks are defined in the text. Bars indicate standard deviation 


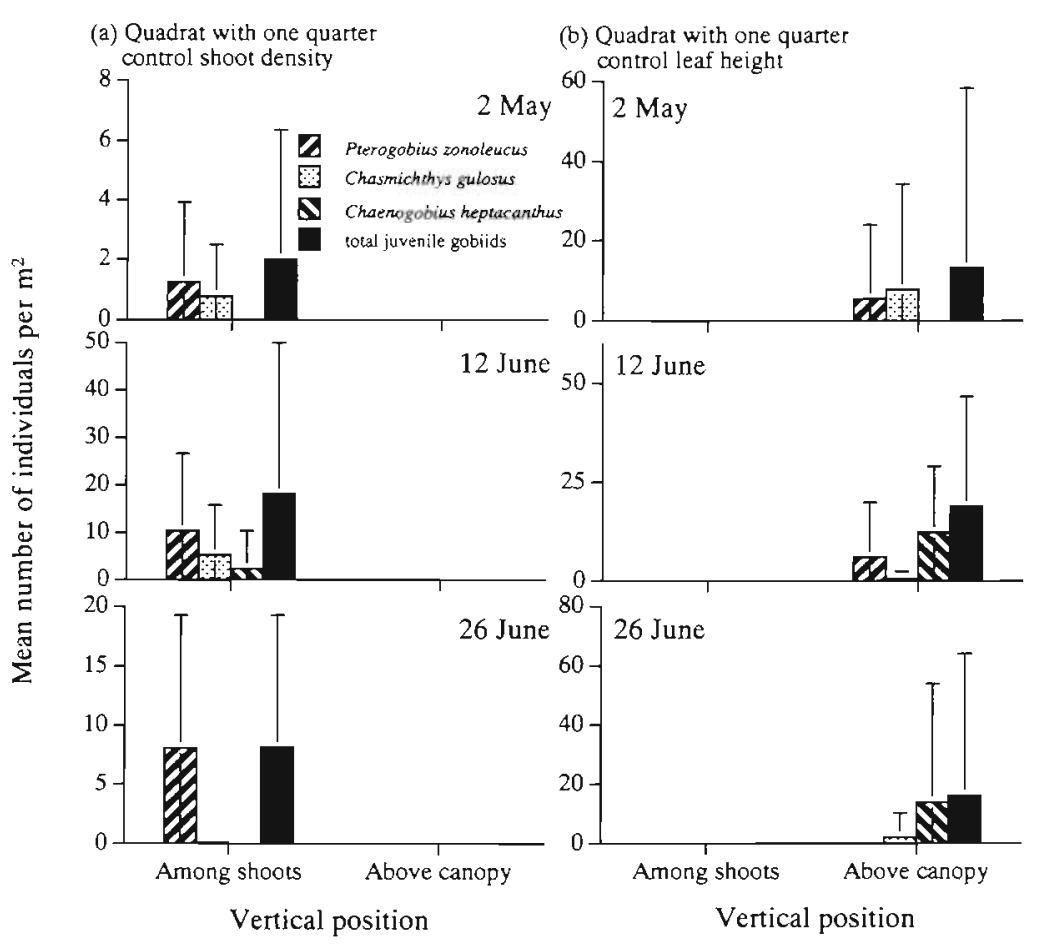

Fig. 6. Vertical distribution of gobiid juveniles in the quadrats with one quarter control (a) shoot density and (b) leaf height. Bars indicate standard deviation

gested a habitat preference for sparser seagrass by juveniles of all 3 gobiid species.

Juveniles appeared more frequently in the quadrats with shorter seagrass, usually forming large mixed-species groups in the open area above the canopy of shortened seagrass, adjacent to the walls of unmanipulated seagrass surrounding the quadrat. Similarly, in the seagrasscleared quadrat, large groups were positioned near the surrounding walls of untreated seagrass. However, no juveniles occurred in the seagrass-manipulated patches in Aburatsubo Bay, which lacked surrounding walls of untreated seagrass, suggesting that juvenile preference was for an open space adjacent to seagrass, rather than for shortened seagrass. Such a wall-like structure also occurs at outer edges of Zostera beds or adjacent to the sand patches within a seagrass bed (identical to the seagrasscleared quadrat). Compared with those inside a Zostera bed, juvenile gobies in such microhabitats are significantly more abundant, often forming large groups

blocks (Fig. 5b). Similarly, all of the juveniles were restricted to the marginal blocks in the seagrasscleared quadrat (Fig. 5c).

\section{Vertical distribution}

In the quadrat with one quarter control shoot density, all of the juveniles appeared among the seagrass shoots (Fig. 6a). By contrast, almost all of the individuals appeared above the canopy of shortened seagrass in the quadrat with one quarter control leaf height (Fig. 6b). Several juvenile Chaenogobius heptacanthus appeared among seagrass shoots on 12 June, but the density was significantly lower than that in the water column above the canopy (Mann-Whitney test, $\mathrm{p}=0.05$ ).

\section{DISCUSSION}

In the experimental Zostera bed in Moroiso Bay, juvenile densities of Pterogobius zonoleucus, Chaenogobius heptacanthus and Chasmichthys gulosus were higher in the quadrats with sparser seagrass, and the group size was larger than that in the control quadrat. Juveniles resided among the shoots, and were evenly distributed over a horizontal plane. These results sug-
(Horinouchi 1997). These results contradict views that habitats with greater structural complexity support a greater abundance of fishes.

Several possible explanations for such a habitat use can be offered. Predation sometimes plays an important role in the structuring of a fish community (e.g. Hixon \& Beets 1993, Carr \& Hixon 1995, Beets 1997) and can influence both fish behaviors and activity patterns (e.g. Hobson 1973, Savino \& Stein 1989). However, the densities of carnivorous fish which preyed on the juveniles were relatively low in the study area; therefore, predation pressure may not be the important factor determining the juvenile densities in the seagrass habitats. Hydrodynamics sometimes plays an important role in determining the distribution patterns of small fish. Breitburg et al. (1995), for example, found that larvae of Gobiosoma bosc actively selected a lowflow microhabitat associated with the downcurrent sides of structures. In the present study, the greater abundance in open areas close to walls of Zostera leaves may indicate their preference for low-flow microhabitats, owing to possible wave attenuation at such sites. Nevertheless, because flow velocities are reduced considerably inside a seagrass bed compared to the outside (Ackerman 1986), the fewer juveniles observed within beds as compared to the outer edge (Horinouchi 1997) suggests that additional important factors determine this behavior. 
Oscillation of Zostera leaves in time with water motion may explain habitat preference of juveniles. At the present study sites, flapping or undulating movements of seagrass blades were regularly observed, sometimes with high amplitudes. Because such movements may result in substantial physical disturbance to small fish in the water column among the seagrass shoots, the juveniles may prefer sparser seagrass or the outer edge of the seagrass bed.

Alternatively, goby juveniles may characteristically form groups and position themselves near a structure, accounting for the abundance patterns observed in the present study. Dense seagrass may prevent juveniles from forming larger groups, because of the lack of space among the seagrass shoots. The sparser seagrass, with greater among-shoot space, may enable juveniles to form larger groups, resulting in their greater abundance. Similarly, greater abundances in the seagrass-shortened and seagrass-cleared quadrats may be explained by the abundant space created above the shortened seagrass or the seagrass-removed substratum, respectively, which allow juveniles to form larger groups.

In addition to facilitating group formation, the characteristic positioning of juveniles close to a significant habitat structure may account for their distribution patterns. In the sparser seagrass, larger groups of juveniles could position themselves close to each Zostera shoot, because of the sufficient among-shoot space, thereby resulting in no apparent difference in juvenile densities between the marginal and central blocks in the shoot density-manipulated quadrats. In the seagrass height-manipulated and seagrass-cleared quadrats, however, the only structures available for large groups of juveniles were the surrounding walls of unmanipulated Zostera leaves which resulted from the above manipulations. This could have resulted in the greater abundance of juveniles in open spaces close to a seagrass wall, in addition to the greater juvenile abundance at the outer edge of the Zostera bed.

The distribution patterns of these water-column juveniles of the 3 gobiid fish documented here seems to have resulted from 1 or a combination of the abovementioned mechanisms. Further research is needed to evaluate the relative importance of these and other mechanisms including food availability (Levin 1994, Levin et al. 1997).

Acknowledgements. We are grateful to Masaaki Morisawa, Hideo Suzuki, Minoru Sekimoto, Mamoru Sekifuji, Yasuo Yamazaki, Hiroshi Kabasawa and the staff of the Misaki Marine Biological Station, University of Tokyo, for their generous assistance in the field work. Constructive comments on the manuscript from Graham Hardy, Hisashi Kurokura, Makoto Shimizu, Toru Taniuchi, Charles Birkeland and
3 anonymous reviewers were much appreciated. We thank the Moroiso fishermen's Union for their permission to dive using SCUBA equipment. This paper is a contribution from the Misaki Marine Biological Station

\section{LITERATURE CITED}

Ackerman JD (1986) Mechanistic implications for pollination in the marine angiosperm Zostera marina. Aquat Bot 24: $343-353$

Adams SM (1976) The ecology of eelgrass, Zostera marina (L.), fish communities. I. Structural analysis. J Exp Mar Biol Ecol 22:269-291

Akihito (1988) Family Gobiidae. In: Masuda H, Amaoka K, Araga C. Uyeno T, Yoshino $T$ (eds) The fishes of the Japanese Archipelago, 2nd edn. Tokai Univ Press, Tokyo, p 230-276 (English text and plates)

Beckley LE (1983) The ichthyofauna associated with Zostera capensis Setchell in the Swartkops estuary, South Africa. $S$ Afr J Zool 18:15-24

Beets JP (1997) Effects of a predatory fish on the recruitment and abundance of Caribbean coral reef fishes. Mar Ecol Prog Ser 148:11-21

Bell JD, Pollard DA (1989) Ecology of fish assemblages and fisheries associated with seagrasses. In: Larkum AWD, McComb AJ, Shepherd SA (eds) Biology of seagrasses. Elsevier, Amsterdam, p 536-564

Bell JD, Westoby M (1986a) Importance of local changes in leaf height and density to fish and decapods associated with seagrasses. J Exp Mar Biol Ecol 104:249-274

Bell JD, Westoby M (1986b) Variation in seagrass height and density over a wide spatial scale: effects on common fish and decapods. J Exp Mar Biol Ecol 104:275-295

Bell JD, Westoby $M$ (1986c) Abundance of macrofauna in dense seagrass is due to habitat preference, not predation. Oecologia (Berl) 68:205-209

Breitburg DL, Palmer MA, Loher T (1995) Larval distributions and the spatial patterns of settlement of an oyster reef fish: responses to flow and structure. Mar Ecol Prog Ser 125:45-60

Carr MH, Hixon MA (1995) Predation effects on early postsettlement survivorship of coral-reef fishes. Mar Ecol Prog Ser 124:31-42

Connoly RM (1994a) A comparison of fish assemblages from seagrass and unvegetated areas of a Southern Australian Estuary. Aust J Mar Freshw Res 45:1033-1044

Connoly RM (1994b) Removal of seagrass canopy: effects on small fish and their prey. J Exp Mar Biol Ecol 184:99-110

Crowder LB, Cooper WE (1982) Habitat structural complexity and the interaction between bluegills and their prey. Ecology 63:1802-1813

Diehl S (1993) Effects of habitat structure on resource availability, diet and growth of benthivorous perch, Perca fluviatilis. Oikos 67:403-414

Diehl S, Eklöv P (1995) Piscivore-mediated habitat use in fish: effects on invertebrate resources, diet and growth of perch, Perca fluviatilis. Ecology 76:1712-1726

Edgar GJ, Shaw C (1995) The production and trophic ecology of shallow-water fish assemblages in southern Australia. I. Species richness, size-structure and production of fishes in Western Port Victoria. J Exp Mar Biol Ecol 194:53-81

Gilinsky E (1984) The role of fish predation and spatial heterogeneity in determining benthic community structure. Ecology 65:455-468

Hixon MA, Beets JP (1993) Predation, prey refuges, and the structure of coral-reef fish assemblages. Ecol Monogr 63: $77-101$ 
Hobson ES (1973) Diel feeding migrations in tropical reef fishes. Helgol Wiss Meeresunters 24:361-370

Horinouchi M (1997) The structure and constructing mechanisms of fish assemblage in Zostera beds at Aburatsubo, Central Japan. Unpubl. Doctoral thesis, University of Tokyo (in Japanese)

Horinouchi M, Sano M, Taniuchi T, Shimizu M (1999) Effects of changes in leaf height and shoot density on the abundance of 2 fishes, Rudarius ercodes and Acentrogobius pflaumi, in a Zostera bed. Ichthyol Res 46:49-56

Leber KM (1985) The influence of predatory decapods, refuge and microhabitat selection on seagrass communities. Ecology 66:1951-1964

Levin P (1994) Small-scale recruitment variation in a temperate fish: the roles of macrophytes and food supply. Environ Biol Fish 40:271-281

Levin P, Petrik R, Malone $J$ (1997) Interactive effects of habitat selection, food supply and predation on recruitment of an estuarine fish. Oecologia 112:55-63

Kikuchi T (1974) Japanese contributions on consumer ecology in eelgrass (Zostera marina L.) beds, with special refer-

Editorial responsibility: Charles Birkeland (Contributing Editor), Mangilao, Guam ence to trophic relationships and resources in inshore fisheries. Aquaculture 4:145-160

Orth RJ, Heck KL Jr (1980) Structural components of the eelgrass Zostera marina meadows in the lower Chesapeake Bay-fishes. Estuaries 3:278-288

Poliard DA (1984) A review of ecological studies on seagrass fish communities with particular reference to recent studies in Australia. Aquat Bot 18:3-42

Savino JF, Stein RA (1989) Behavior of tish predators and their prey: habitat choice between open water and dense vegetation. Environ Biol Fish 24:287-293

Sogard SM (1992) Colonization of artificial seagrass by fishes in different estuarine habitats. Mar Ecol Prog Ser 85:35-53

Weinstein MP, Heck KL Jr (1979) Ichthyofauna of seagrass meadows along the Caribbean coast of Panama and in the Gulf of Mexico: composition, structure and community ecology. Mar Biol 50:97-107

Worthington DG, Ferrell DJ, McNeil SE, Bell JD (1992) Effects of the shoot density of seagrass on fish and decapods: are correlations evident over larger spatial scales? Mar Biol 112:139-146

Submitted: July 26, 1998; Accepted: February 2, 1999

Proofs received from author(s): June 24, 1999 